\title{
BACTERIOLOGICAL CONTAMINATION OF WATER IN SELECTED BATHING AREAS IN MAŁOPOLSKA
}

\section{ZANIECZYSZCZENIE BAKTERIOLOGICZNE WÓD WYBRANYCH KĄPIELISK NA TERENIE MAŁOPOLSKI}

\author{
Department of Microbiology, University of Agriculture, Kraków, Poland
}

\begin{abstract}
Streszczenie. Mikrobiologiczne zanieczyszczenie wód wykorzystywanych do celów rekreacyjnych może stanowić poważne zagrożenie dla zdrowia użytkowników. Tylko nieliczne zbiorniki wodne w Małopolsce podlegają stałej kontroli i spełniają kryteria mikrobiologiczne. Celem pracy była ocena stopnia mikrobiologicznego zanieczyszczenia wybranych kąpielisk znajdujących się w województwie małopolskim w gminach Tarnów i Kraków. Próbki do badań pobrano z 10 kąpielisk trzykrotnie w okresie od czerwca do października 2016 r. Analizy mikrobiologiczne wody wykonano metodą filtracji membranowej i metodą seryjnych rozcieńczeń. Określono ogólną liczbę bakterii mezofilnych i psychrofilnych oraz liczebność Escherichia coli, paciorkowców kałowych (enterokoków) i gronkowców. We wszystkich badanych kąpieliskach stwierdzono występowanie mikrobiologicznych wskaźników złego stanu higienicznego wody. Bardzo licznie występowały bakterie $E$. coli, co było główną przyczyną zaliczenia zbiorników do niespełniających wymagań stawianych kąpieliskom. Bardziej zanieczyszczone bakteriami były kąpieliska na terenie gminy Kraków, niż na terenie gminy Tarnów, jednak nie były to różnice istotne. Liczebność bakterii psychrofilnych w wodach była większa niż bakterii mezofilnych, co sugeruje, że głównym źródłem pochodzenia drobnoustrojów jest środowisko naturalne. Tereny rekreacyjne objęte stałym monitoringiem charakteryzowały się nieco mniejszym ogólnym zanieczyszczeniem bakteriologicznym, jednak rzadko spełniały kryteria stawiane kąpieliskom ze względu na dużą liczebność bakterii wskaźnikowych. Największe zanieczyszczenie wód stwierdzono w szczycie sezonu turystycznego - w sierpniu. Biorąc pod uwagę wartości średnie pomiarów, jedynie kąpielisko Katamaran spełniało wymagania.
\end{abstract}

Key words: bathing areas, bacteriological contamination, Escherichia coli, enterococci, staphylococci.

Słowa kluczowe: kąpieliska, zanieczyszczenie bakteriologiczne, Escherichia coli, paciorkowce kałowe, gronkowce

\section{INTRODUCTION}

The terms „bathing pool” or "bathing area” are commonly used for most water bodies used for bathing and recreational purposes, however - legally - there are only a few in Poland. In the Małopolskie voivodeship, since 2011, there is only one bathing area, based on the amended national requirements, subordinated to the requirements of EU Directive 2006/7 / EC of the European Parliament and of the Council of 15 February 2006 concerning the management

Corresponding author - Adres do korespondencji: Maria J. Chmiel, Department of Microbiology, University of Agriculture, Adama Mickiewicza 24/28, 30-059 Kraków, Poland, e-mail: maria.chmiel@ur.krakow.pl 
of bathing water quality (Dyrektywa 2006/7/WE Parlamentu Europejskiego i Rady z dnia 15 lutego 2006 r.; Państwowy Powiatowy Inspektorat Sanitarny w Krakowie 2016).

The bathing area, according to the Act of 4 March 2010 (Ustawa z dnia 4 marca 2010 r.), is an object approved by the Commune Council, meeting the relevant formal requirements and showing high standards in technical and sanitary infrastructure. For the time of adapting the waters to bathing requirements, they shall be referred to as the „place used for bathing”. They are subject to more stringent requirements in terms of water quality and infrastructure as well as the cost of meeting the formal requirements. However, according to the Regulation of the Minister of Health of 2011 on the supervision of the quality of bathing area and the place used for bathing, the quality of water in both bodies of water shall be periodically assessed in at least 4 (bathing areas) or 2 times (bathing areas) - one of which must be carried out before the beginning of the bathing season.

In Poland, sanitary supervision of the suitability of bathing areas in selected bodies of water is held by Sanitary-Epidemiological Stations and State District Sanitary Inspectorates. Legislation and standards in Poland currently provide microbiological bathing areas tests for fecal streptococci (enterococci) and Escherichia coli. However, it seems appropriate to analyze the total number of mesophilic and psychophilic bacteria in recreationally used waters, as this may indicate a constant influx of pollutants (Chmiel 2013; Chmiel et al. 2016) into the bathing areas - while regulation does not require that. There is also no obligation to test bathing waters for the presence of coagulase-positive staphylococci, although in studies conducted already in the 1980s of the last century, it has been found that they are the most common cause of illness among swimmers (Seyfried et al. 1985). Recent data analysis also highlights the importance of surface waters as a temporary reservoirs and a source of staphylococci - including antibiotic resistant strains (Gómez et al. 2017). Therefore, the lack of such studies may increase the risk of infecting tourists using this form of recreation. Thus microbiological contamination of waters used for recreational purposes may constitute a serious danger to the health of users.

Contamination of water environments is a worldwide problem, but in Poland which is ranked among the countries with poor water resources (Gutry-Korycka et al. 2014) its poor quality can be particularly acute. Recreational areas with water reservoirs are very popular in Małopolska voivodeship, but only a few bathings in Lesser Poland are subjects of constant control and during the entire tourist season meet the microbiological criteria (Państwowy Inspektorat Sanitarny w Krakowie 2016).

The work was aimed at evaluating the degree of water contamination of ten selected bathing areas located in the municipal areas of Tarnow and Krakow based on bacteriological indicators such as total number of mesophilic and psychrophilic bacteria, enterococci, staphylococci and Escherichia coli.

\section{MATERIAL AND METHODS}

Samples of water for bacteriological examination were collected from water reservoirs used for bathing and recreation located in the municipality of Kraków and Tarnów. Samples were collected in triplicates from ten locations (Table 1) - five points in Krakow region and 
five in Tarnów region, from June to October 2016 (3rd June, 22nd August, 3rd October) as recommended by standards and regulations (PN-EN ISO 19458 : 2007; Rozporządzenie Ministra Zdrowia z dnia 8 kwietnia 2011 r.). During the sampling water and air temperature was measured.

Table 1. Sampling points location

Tabela 1. Lokalizacja punktów pobrania wody

\begin{tabular}{|c|c|c|c|c|}
\hline $\begin{array}{l}\text { Sampling } \\
\text { point } \\
\text { Punkt } \\
\text { pobrania }\end{array}$ & $\begin{array}{l}\text { Bathing area } \\
\text { Kąpielisko }\end{array}$ & $\begin{array}{l}\text { Locality } \\
\text { Miejscowość }\end{array}$ & $\begin{array}{c}\text { Longitude } \\
\text { and latitude } \\
\text { Długość } \\
\text { i szerokość } \\
\text { geograficzna }\end{array}$ & $\begin{array}{l}\text { Sanitary condition } \\
\text { monitoring body } \\
\text { Organ monitorujący } \\
\text { stan sanitarny }\end{array}$ \\
\hline \multicolumn{5}{|c|}{ Tarnów district - Powiat Tarnów } \\
\hline 1 & $\begin{array}{l}\text { Private Fishing Holiday Center Prywatny } \\
\text { Ośrodek Wypoczynkowo Wędkarski } \\
\text { „Katamaran” }\end{array}$ & Radłowo & $\begin{array}{l}20^{\circ} 50^{\prime} 41.7 " \mathrm{E} \\
50^{\circ} 04^{\prime} 19.8 " \mathrm{~N}\end{array}$ & $\begin{array}{l}\text { SDSI in Tarnów } \\
\text { PPIS w Tarnowie }\end{array}$ \\
\hline 2 & Bathing area - Kąpielisko Dwudniaki & Dwudniaki & $\begin{array}{l}20^{\circ} 49^{\prime} 49.9^{\prime \prime} \mathrm{E} \\
50^{\circ} 02^{\prime} 19.1^{\prime \prime} \mathrm{N} \\
\end{array}$ & $\begin{array}{l}\text { SDSI in Tarnów } \\
\text { PPIS w Tarnowie }\end{array}$ \\
\hline 3 & Lagoon - Zalew Kakałko & $\begin{array}{l}\text { Podlesie } \\
\text { Dębowe }\end{array}$ & $\begin{array}{l}20^{\circ} 52^{\prime} 59.2 " \mathrm{E} \\
50^{\circ} 09^{\prime} 10.4 " \mathrm{~N}\end{array}$ & $\begin{array}{l}\text { SDSI in Tarnów } \\
\text { PPIS w Tarnowie }\end{array}$ \\
\hline 4 & $\begin{array}{l}\text { Bathing area on Dunajec river near } \\
\text { Zgłobice } \\
\text { Kąpielisko na Dunajcu k. Zgłobic }\end{array}$ & Zgłobice & $\begin{array}{l}20^{\circ} 52^{\prime} 54.4^{\prime \prime} \mathrm{E} \\
49^{\circ} 57^{\prime} 47.0^{\prime \prime} \mathrm{N}\end{array}$ & NM \\
\hline 5 & $\begin{array}{l}\text { Bathing area on Dunajec river near } \\
\text { Ostrów } \\
\text { Kąpielisko na Dunajcu k. Ostrowa }\end{array}$ & Ostrów & $\begin{array}{l}20^{\circ} 53^{\prime} 23.5 " \mathrm{E} \\
50^{\circ} 00^{\prime} 39.6 " \mathrm{~N}\end{array}$ & NM \\
\hline \multicolumn{5}{|c|}{ Kraków district - Powiat Kraków } \\
\hline 6 & Lagoon - Zalew Na Piaskach & Kryspinów & $\begin{array}{l}19^{\circ} 79^{\prime} 59.0^{\prime \prime} \mathrm{E} \\
50^{\circ} 05^{\prime} 17.9^{\prime \prime} \mathrm{N} \\
\end{array}$ & $\begin{array}{l}\text { SDSI in Kraków } \\
\text { PPIS w Krakowie }\end{array}$ \\
\hline 7 & Lagoon - Zalew Zakrzówek & Kraków & $\begin{array}{l}19^{\circ} 91^{\prime} 14.5^{\prime \prime} \mathrm{E} \\
50^{\circ} 03^{\prime} 74.4^{\prime \prime} \mathrm{N}\end{array}$ & $\begin{array}{l}\text { SDSI in Kraków } \\
\text { PPIS w Krakowie }\end{array}$ \\
\hline 8 & Lagoon - Zalew Bagry & Kraków & $\begin{array}{l}19^{\circ} 99^{\prime} 34.5^{\prime \prime} \mathrm{E} \\
50^{\circ} 03^{\prime} 32.7^{\prime \prime} \mathrm{N} \\
\end{array}$ & $\begin{array}{l}\text { SDSI in Kraków } \\
\text { PPIS w Krakowie }\end{array}$ \\
\hline 9 & Gravel pits - Żwirownia Brzegi & Brzegi & $\begin{array}{l}20^{\circ} 08^{\prime} 63.6^{\prime \prime} \mathrm{E} \\
50^{\circ} 03^{\prime} 41.1^{\prime \prime} \mathrm{N} \\
\end{array}$ & NM \\
\hline 10 & $\begin{array}{l}\text { Bathing area - Kąpielisko Przylasek } \\
\text { Rusiecki }\end{array}$ & Kraków & $\begin{array}{l}20^{\circ} 16^{\prime} 10.7 " \mathrm{E} \\
50^{\circ} 05^{\prime} 00.1 " \mathrm{~N}\end{array}$ & $\begin{array}{l}\text { SDSI in Kraków } \\
\text { PPIS w Krakowie }\end{array}$ \\
\hline
\end{tabular}

SDSI - State District Sanitary Inspectorate - PPIS - Państwowy Powiatowy Inspektorat Sanitarny. $\mathrm{NM}$ - bathing area not monitored - kąpielisko niemonitorowane.

Bacteriological analyzes were carried out by the membrane filtration method as well as by the serial dilution method. For enumeration of indicator bacteria were used: TBX - Tryptone Bile Agar with X-Glucuronide (Biocorp) - a chromogenic medium for the detection of Escherichia coli, SB - Slanetz and Bartley medium (Oxoid) - for the detection of enterococci (fecal streptococci), SA - Chromogenic S. aureus LAB-AGAR (Biocorp) - for staphylococci enumeration. TSA - Trypticasein Soy LAB-AGAR ${ }^{\mathrm{TM}}$ (Biocorp) medium was used to determine the number of total viable count of mesophilic and psychrophilic bacteria (Klapes and Vesley 1986; PN-EN ISO 7899-2 : 2004; PN EN ISO 6222 : 2004; PN-EN ISO 8199 : 2010; PN-EN ISO 9308-1 : 2014-12; Rozporządzenie Ministra Zdrowia z dnia 8 kwietnia 2011 r.; Chmiel 2013; Nollet and De Gelder 2013). After incubation (parameters of incubation showed in Table 2) colonies of bacteria on membranes and plates were counted. Results were recalculated and showed as number of colony forming unit per 1 or $100 \mathrm{~cm}^{3}$ as recommended. Statistical analysis based on calculating mean and standard deviation. 
Table 2. Parameters of bacteria incubation

Tabela 2. Warunki hodowli bakterii

\begin{tabular}{|c|c|c|c|}
\hline $\begin{array}{l}\text { Tested bacteria } \\
\text { Badane bakterie }\end{array}$ & $\begin{array}{c}\text { Temperature } \\
\text { Temperatura } \\
{\left[{ }^{\circ} \mathrm{C}\right]} \\
\end{array}$ & $\begin{array}{c}\text { Time of incubation } \\
\text { Czas hodowli } \\
{[\mathrm{h}]}\end{array}$ & $\begin{array}{c}\text { Volume of tested sample } \\
\text { Objętość badanej próbki } \\
{\left[\mathrm{cm}^{3}\right]}\end{array}$ \\
\hline Escherichia coli & 44 & 24 & 100 \\
\hline $\begin{array}{l}\text { Fecal streptococci } \\
\text { Paciorkowce kałowe }\end{array}$ & 37 & 72 & 100 \\
\hline $\begin{array}{l}\text { Staphylococci } \\
\text { Gronkowce }\end{array}$ & 37 & 48 & 100 \\
\hline $\begin{array}{l}\text { Mesophilic bacteria } \\
\text { Bakterie mezofilne }\end{array}$ & 37 & 24 & 1 \\
\hline $\begin{array}{l}\text { Psychrophilic bacteria } \\
\text { Bakterie psychrofilne }\end{array}$ & 22 & 72 & 1 \\
\hline
\end{tabular}

\section{RESULTS AND DISCUSSION}

Microbiological contamination of water is one of the key indicators that determine the purposes for which water may be used. The essential problem in Poland is not only water deficit but also the low quality of surface water, among others, due to their contamination by microorganisms. Issues relating to the monitoring of surface water status is governed by numerous Regulation of the Minister of the Environment by setting the frequency and scope of the research, depending on the type of water (flowing water, tanks) and its usage. Although in recent years the quality of the water has improved still little more than $30 \%$ of the examined rivers and reservoirs can be classified as good quality water (OECD Report 2015).

The greatest threat to human health can be the reservoirs from which water is taken for consumption and used for the recreational purposes of the bathing resort. Water intended for consumption is treated and routinely tested - unfortunately, bathing areas are no longer subject of such stringent control and can therefore be a potential source of bacterial infections.

Although the temperatures of the water in the municipality of Krakow were higher than in the area of Tarnow it is not possible to conclude that the water was a factor significantly affecting number of bacteria. The lowest water temperatures were noted in bathings Dunajec (sampling points 4,5) (Fig. 1) but waters were significantly contaminated by bacteria (Fig. 2, 3). Results obtained by Chmiel et al. (2017) also indicate high pollution of Dunajec waters with Escherichia coli strains. Low temperatures of water don't create favorable conditions for the growth of microorganisms in water, but the time of survival of same species in low temperatures can extend (Van Elsas et al. 2011), posing a greater threat to users of reservoirs.

The quality of bathing in Poland is supervised by the Ministry of Health. The Regulation of the Minister of Health of 2011 (Rozporządzenie Ministra Zdrowia z dnia 8 kwietnia 2011 r.) defines the (among others) microbiological parameters in the assessment of bathing areas by providing a water test to determine the number of enterococci and Escherichia coli.

Analyzing data on the number of fecal streptococci (enterococci) and E. coli (Fig. 3) can be stated that none of bathing areas did not meet the criteria throughout the whole study period. Taking into account the average pollution - the bathing "Katamaran" meet the requirements of the Regulation of the Minister of Health. 


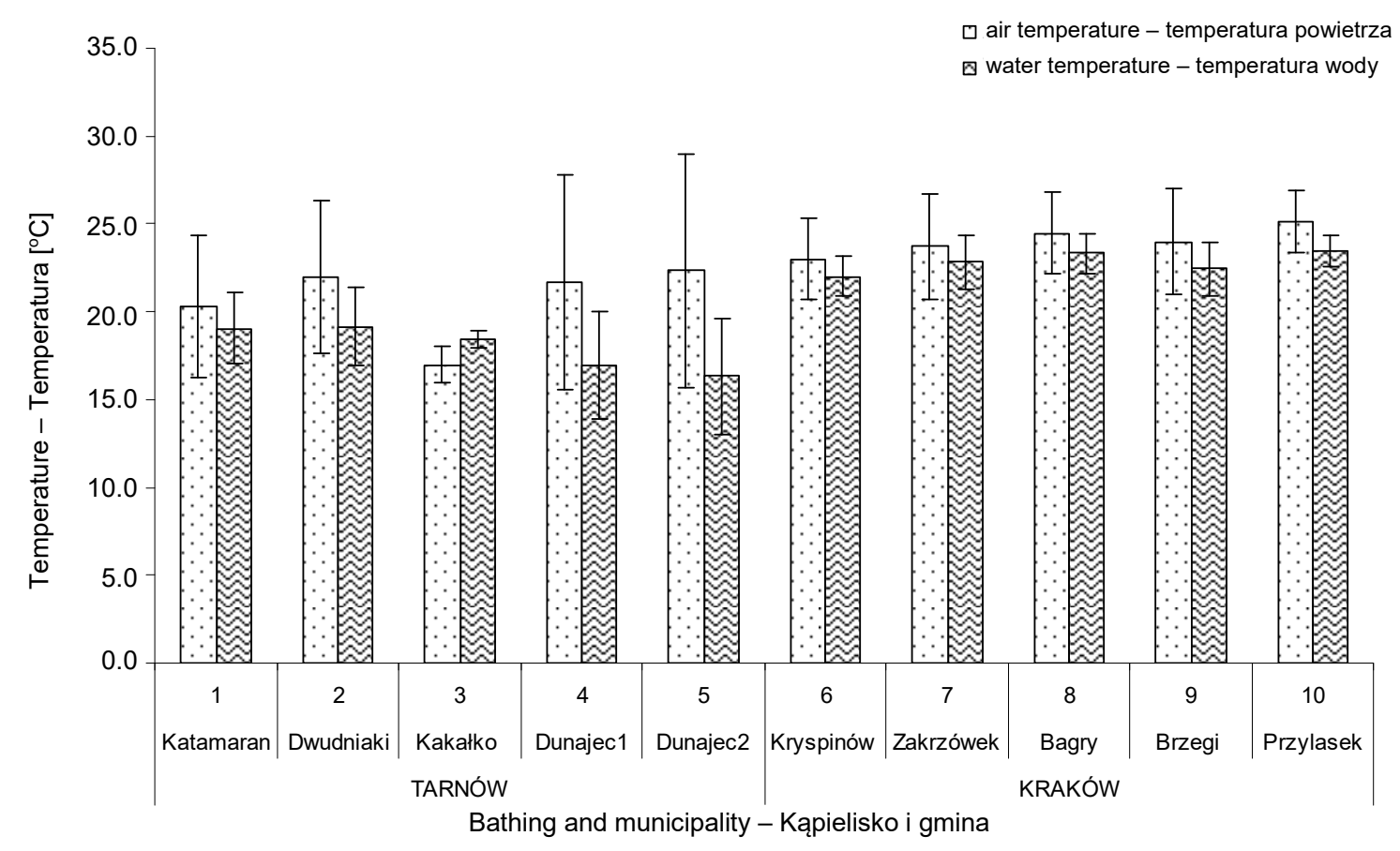

Fig. 1. Mean water and air temperatures depending on the location of the bathing area Ryc. 1. Średnie wartości temperatury wody i powietrza w zależności od lokalizacji kąpieliska

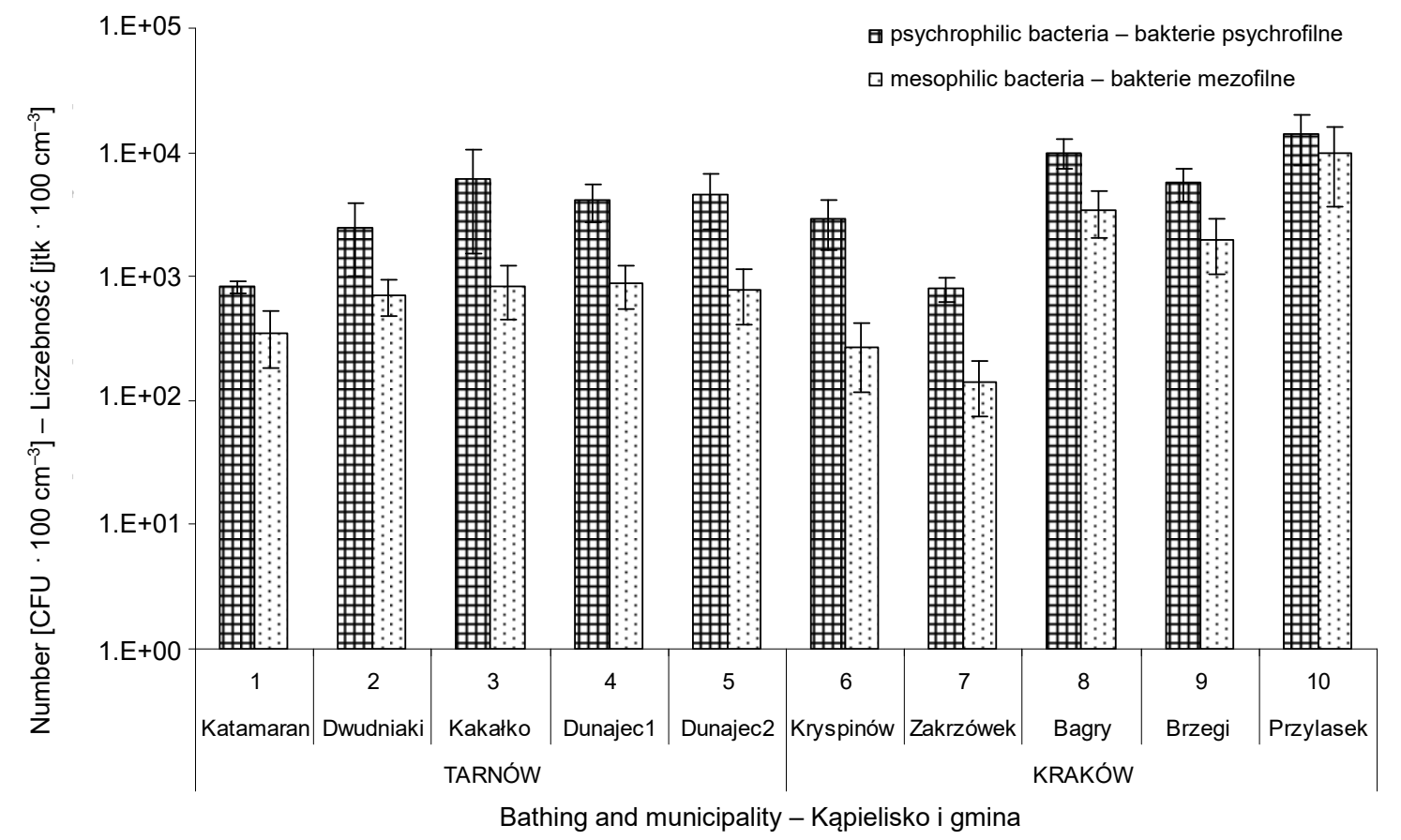

Fig. 2. Mean total number of bacteria in the waters of the tested bathing sites Ryc. 2. Średnia ogólna liczba bakterii w wodach badanych kąpielisk 


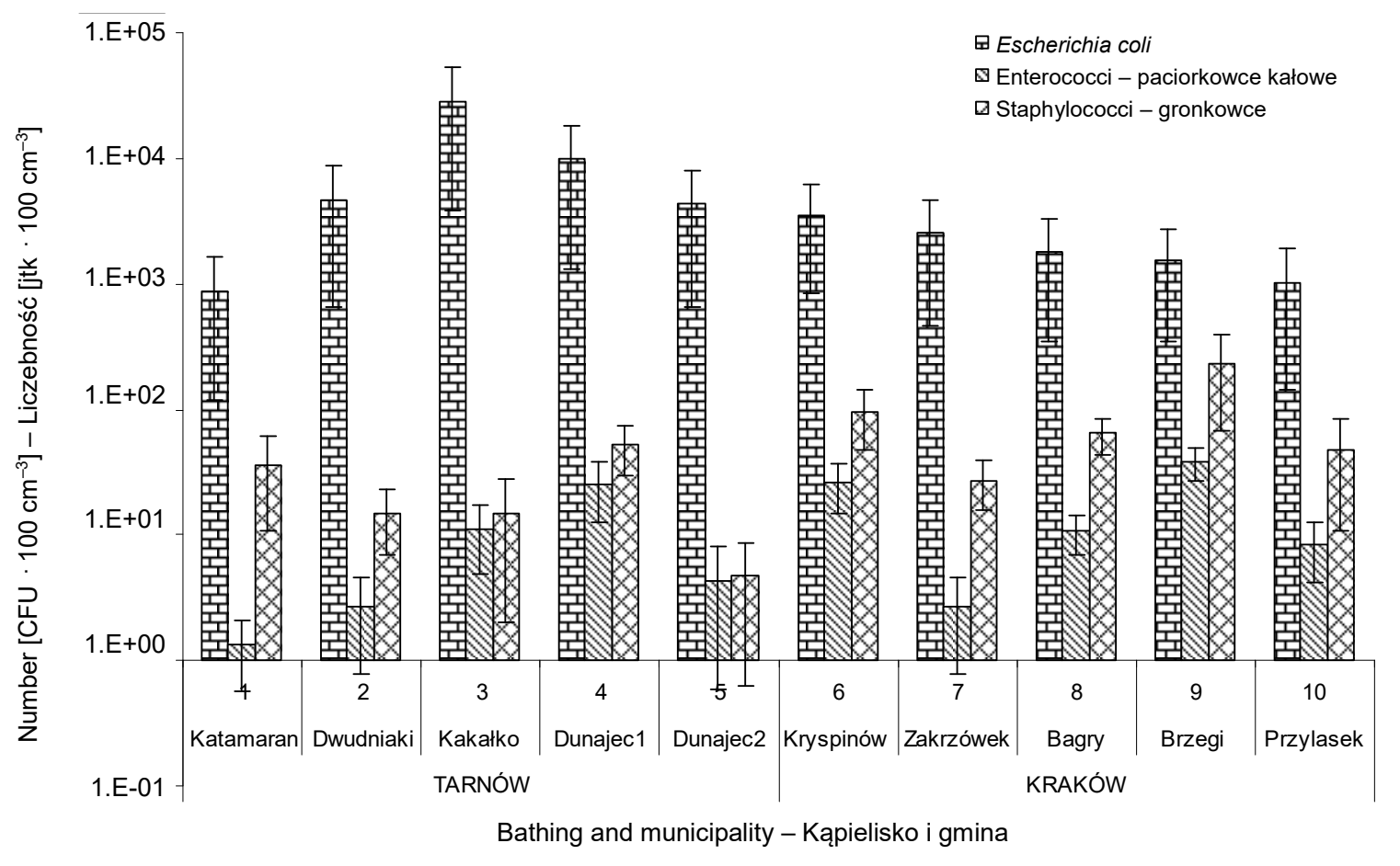

Fig. 3. Mean number of indicator bacteria in the waters of the tested bathing sites Ryc. 3. Średnia liczebność bakterii wskaźnikowych w wodach badanych kąpielisk

In the case of enterococci the number of colony forming units should be less than or equal to 400 , while water testing to determine the number of units forming colonies of Escherichia coli 1000 and more in $100 \mathrm{~cm}^{-3}$ of water is considered unacceptable by the Minister of Health (Rozporządzenie Ministra Zdrowia z dnia 8 kwietnia 2011 r.).

According to the State Sanitary Inspectorate in Tarnów, reservoirs in Radłów (1) and Podlesie Dębowe (3) were suitable for bathing in 2016 (Państwowy Powiatowy Inspektorat Sanitarny w Tarnowie 2016a, b). However, as a result of this work, based on mean values of bacteriological contamination only bathing "Katamaran" in Radłów (sampling point 1) meets the criteria of the bathing area. Although in 2015 the waters of the Przylesek Rusiecki bath (sampling point 10) were included in the waters meeting the criteria for the swimming area (Państwowa Stacja Sanitarno-Epidemiologiczna w Krakowie 2015), this study in the next season did not confirm these results. In all bathings numerous occurred bacteria of the species $E$. coli, which was the main reason for most waters has been taken to those that did not meet the bathing area requirements.

In all examined reservoirs the occurrence of microbiological indicators of bad hygienic condition of water was confirmed, but the biggest water pollution by psychrophiles, E.coli and staphylococci was found at the peak of the tourist season in August (Fig. 4, 5).

Recreational areas under constant monitoring were characterized by slightly less bacteriological contamination, but rarely met criteria for bathing due to the large number of indicator bacteria - Escherichia coli (Fig. 6). 


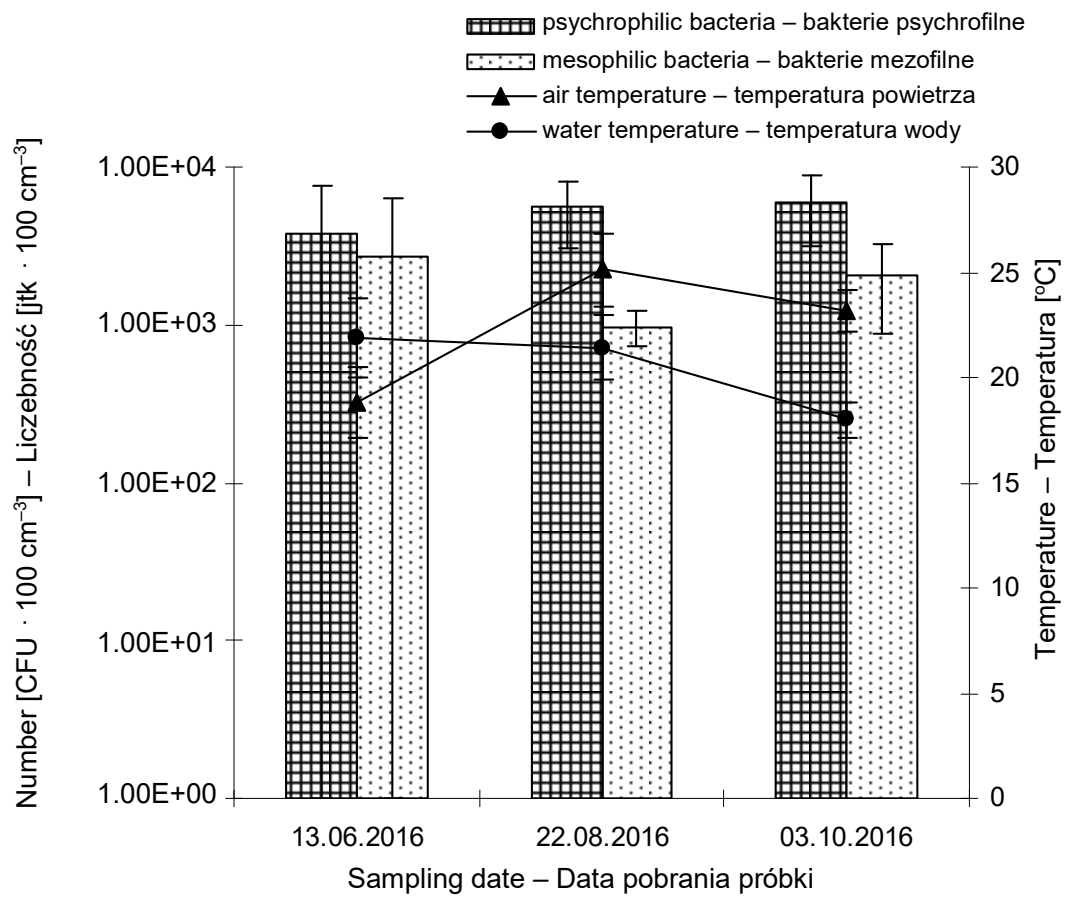

Fig. 4. Mean total number of bacteria and temperatures depending on the water sampling date Ryc. 4. Średnia ogólna liczba bakterii i wartości temperatury w zależności od terminu pobrania wody

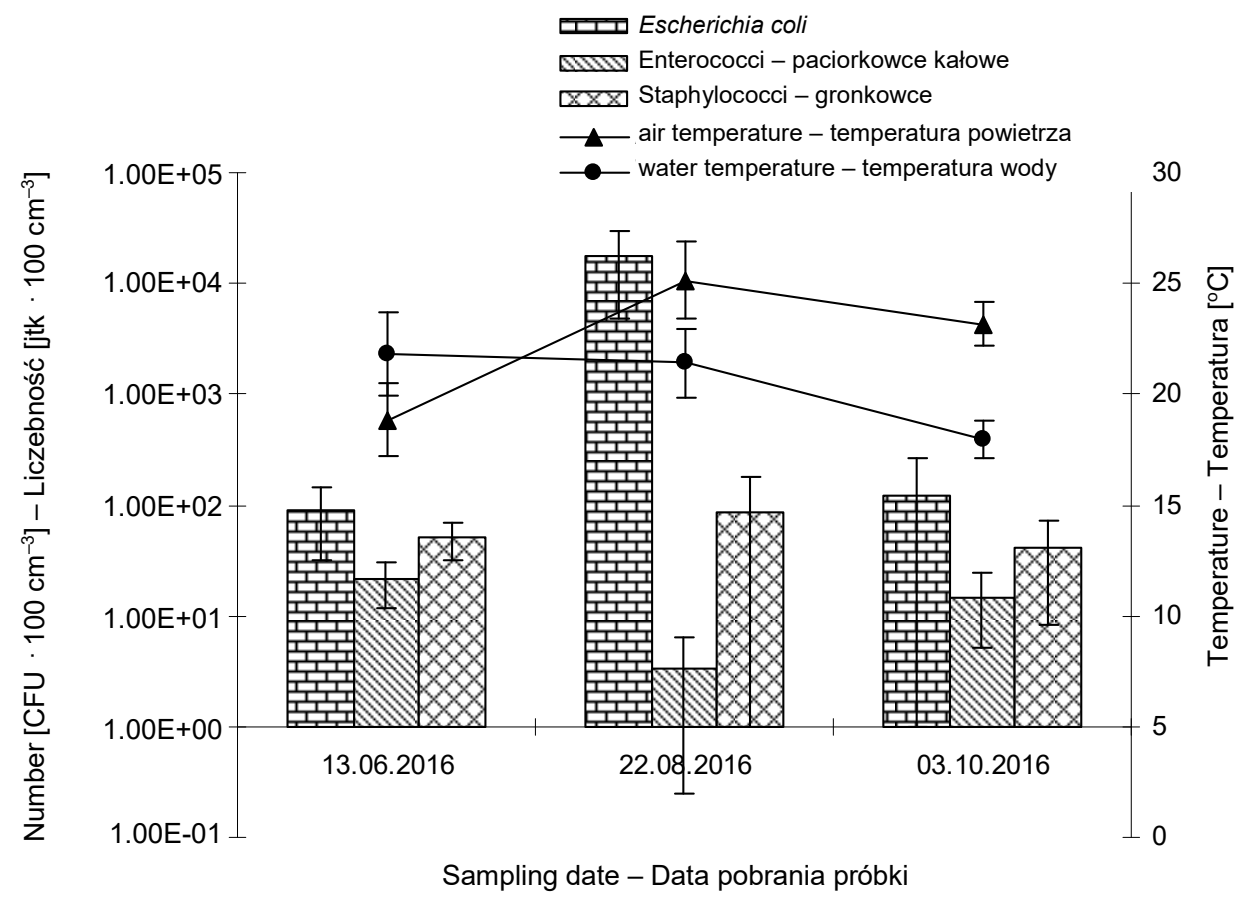

Fig. 5. Mean number of indicator bacteria and temperatures depending on the water sampling date Ryc. 5. Średnia liczba bakterii wskaźnikowych i wartości temperatury w zależności od terminu pobrania wody 

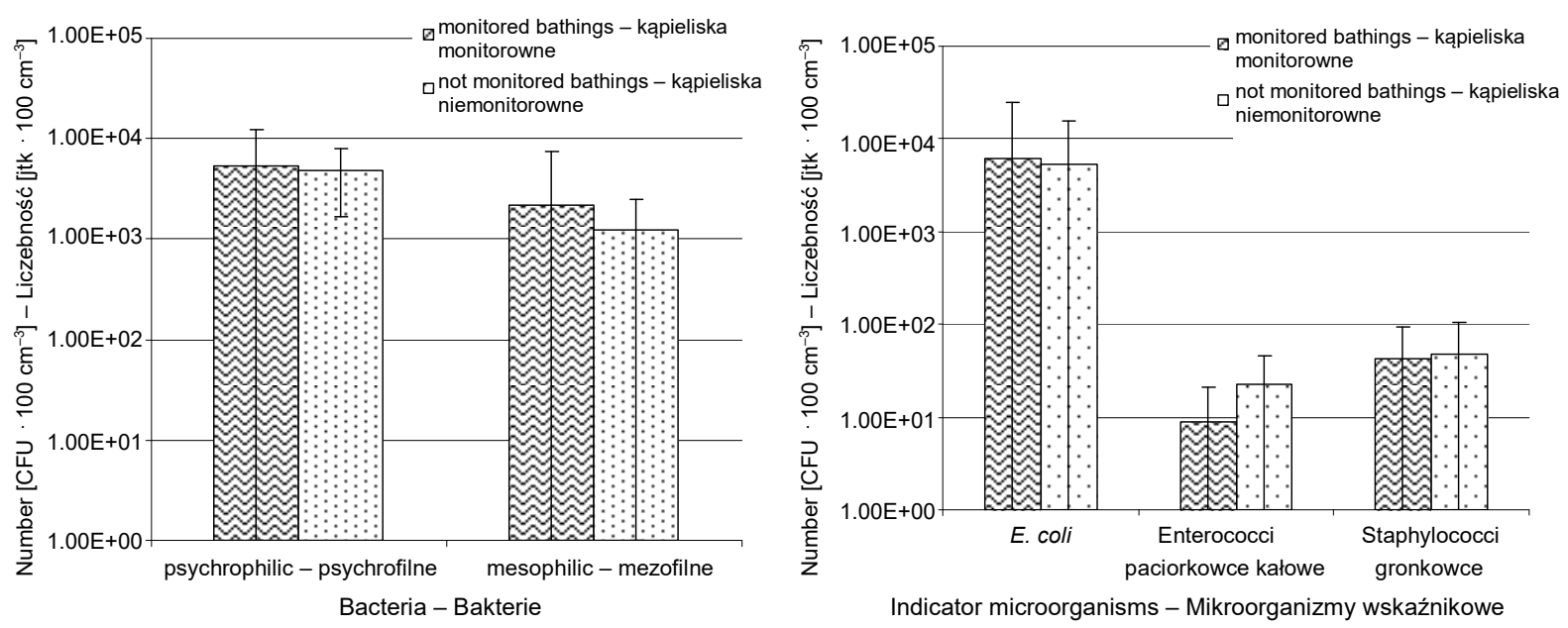

Fig. 6. Mean number of investigated bacteria and indicator microorganisms in monitored and non monitored bathings

Ryc. 6. Średnia liczba badanych bakterii i mikroorganizmów wskaźnikowych w kąpieliskach monitorowanych i niemonitorowanych

The current Polish regulations do not provide an analysis of the total bacteriological contamination of bathing waters, although the presence of mesophilic bacteria may indicate the flow to the water pollution of anthropogenic origin, and pathogens may be present among the numerous bacteria.

Considering the Cabejszek scale (Cabejszek et al. 1960; Niewolak 2000) to assess the quality of surface waters based on the number of mesophilic and psychrophilic bacteria all the reservoirs in the area of the municipality Tarnów (sampling points 1 to 5) can be classified as insignificantly polluted as well as Zakrzówek and Kryspinów in the municipality of Kraków, others are distinctly polluted (Bagry and Brzegi) and even heavily polluted bathing area Przylasek Rusiecki (No. 10).

More contaminated were bathings in the municipality of Kraków than Tarnów (Fig. 7, 8), but these were not statistically significant differences.

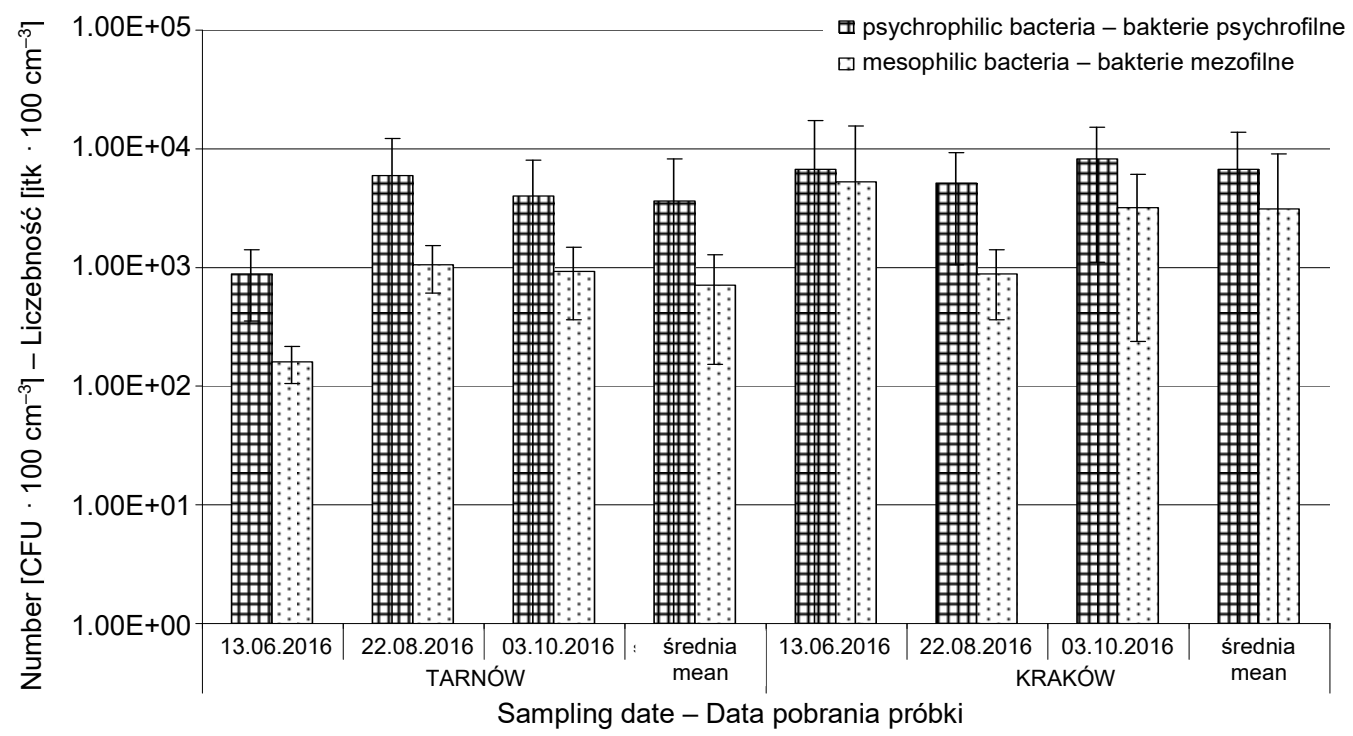

Fig. 7. Mean total number of bacteria depending on the water sampling date and the location (municipality) of bathing area Ryc. 7. Średnia ogólna liczba bakterii w zależności od terminu pobrania wody i lokalizacji gminy (kąpieliska) 


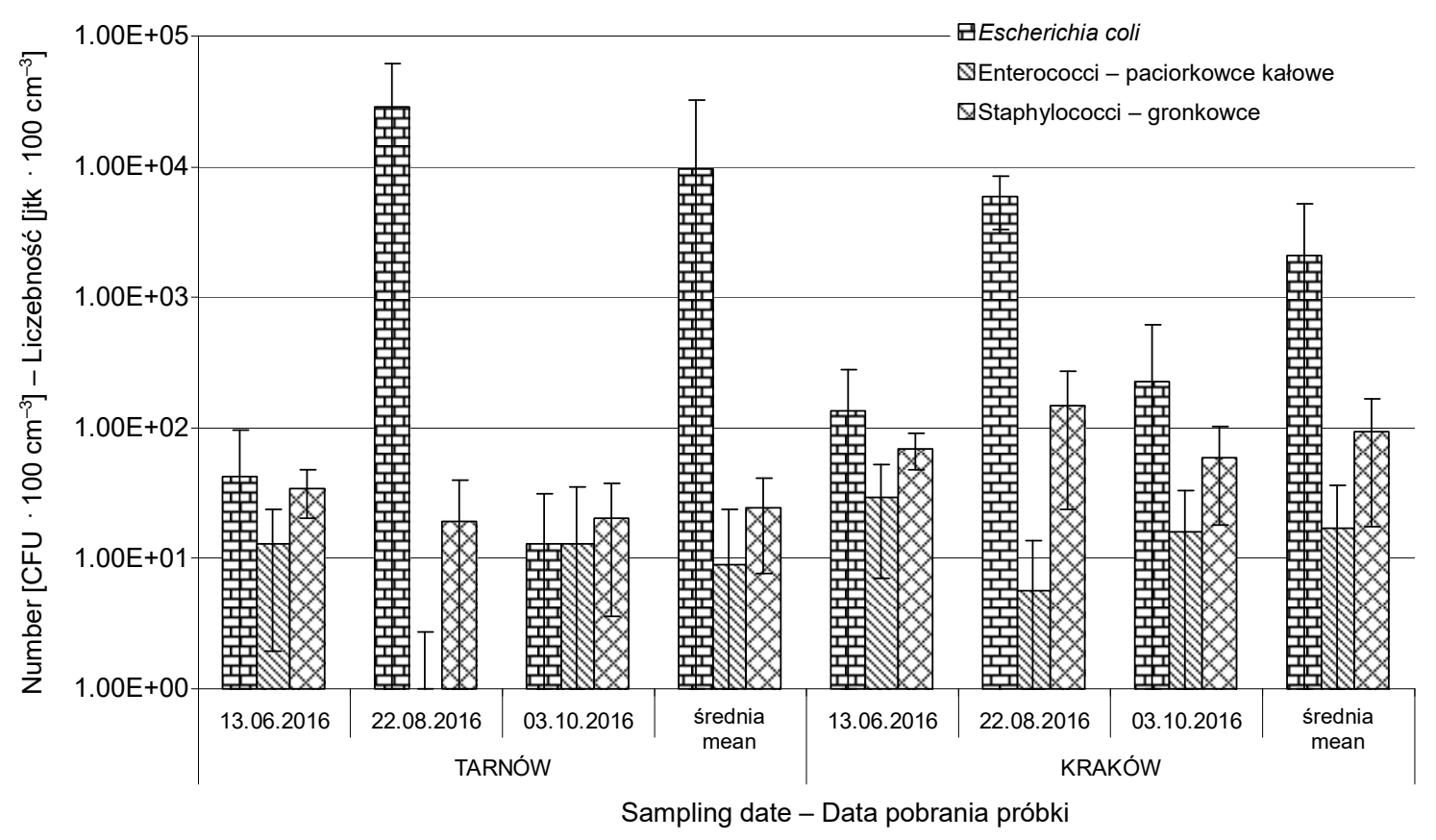

Fig. 8. Mean number of indicator bacteria depending on the water sampling date and the location (municipality) of bathing area

Ryc. 8. Średnia liczba bakterii wskaźnikowych w zależności od terminu pobrania wody i lokalizacji gminy (kąpieliska)

The presence of pathogenic microorganisms in the water poses a risk of infectious diseases (Michałkiewicz and Mądrecka 2009). The Regulation of the Minister of Health (2015) on the quality of water in swimming pools provides testing it for the presence of E. coli, staphylococci, Legionella sp., and Pseudomonas aeruginosa, as well as determining the total number of bacteria - there is no such requirements for bathings, although pathogens posing the greatest risk in bathing waters are staphylococci. This has been proven already in the last century (Seyfried et al. 1985) and this is also confirmed by contemporary research (Gómez et al. 2017) on the spread of drug-resistant staphylococci in water. This study confirmed the numerous occurrences of staphylococci in all bathing areas (Fig. 3, 8), which may pose a risk to those who use these waters, so it is important to draw attention to personal hygiene before and after bathing.

\section{CONCLUSIONS}

1. In all examined reservoirs the occurrence of microbiological indicators of bad hygienic condition of water was confirmed, but the biggest water pollution was found at the peak of the tourist season in August.

2. In bathings numerous occurred bacteria of the species Escherichia coli, which was the main reason for most waters has been taken to those that did not meet the bathing area requirements. 
3. More contaminated were bathing areas in the municipality of Kraków than Tarnów, but these were not statistically significant differences.

4. The number of psychrophilic bacteria in the waters was higher than mesophilic ones, suggesting that the main source of microorganisms is the natural environment.

5. Recreational areas under constant monitoring were characterized by slightly less bacteriological contamination, but rarely met criteria for bathing due to the large number of indicator bacteria - Escherichia coli.

6. Considering the average values of measurements only bathing "Katamaran" meet the requirements of the Regulation of the Minister of Health from 2011.

\section{REFERENCES}

Ustawa z dnia 4 marca 2010 r. o zmianie ustawy Prawo wodne. DzU z 2010 r., nr 44, poz. 253. [in Polish]

Cabejszek J., Kołaczkowski S., Korzeniowski B., Luczak J. 1960. Projekt ujednoliconych wytycznych do klasyfikacji zanieczyszczeń wód powierzchniowych [Project of harmonized guidelines for the classification of surface water pollution]. Gaz Woda 34, 18-22. [in Polish]

Chmiel M. 2013. Charakterystyka mikrobiologiczna i ocena sanitarna środowiska naturalnego Ojcowskiego Parku Narodowego ze szczególnym uwzględnieniem antropopresji. Kraków, Wydaw. UR w Krakowie. [in Polish]

Chmiel M.J., Lis E., Korta-Pepłowska M. 2016. Evaluation of the quality of surface water In the vicinity of wastewater treatment plants based on bacteriological contamination. Folia Pomer. Univ. Technol. Stetin., Agric., Aliment., Pisc., Zootech. 330(40)4, 47-56. DOI: 10.21005/AAPZ2016.40.4.05.

Chmiel M.J., Wójtowicz P., Łojas E. 2017. Evaluation of the quality of surface water in the vicinity of wastewater treatment plants based on bacteriological contamination. Folia Pomer. Univ. Technol. Stetin., Agric., Aliment., Pisc., Zootech. 332(41)1, 5-14. DOI: 10.21005/AAPZ2017.41.1.01.

Dyrektywa 2006/7/WE Parlamentu Europejskiego i Rady z dnia 15 lutego 2006 r. dotycząca zarządzania jakością wody w kąpieliskach i uchylająca dyrektywę 76/160/EWG, http://www.infor.pl/akt-prawny/EOL.2006.064.0000250,metryka,dyrektywa-20067we-parlamentu-europejskiego-i-rady-dotyczaca-zarzadzania-jakoscia-wody-w-kapieliskach-i-uchylajaca-dyrektywe-76 160ewg.html. [in Polish]

Gutry-Korycka M., Sadurski A., Kundzewicz Z.W., Pociask-Karteczka J., Skrzypczak L. 2014. Zasoby wodne a ich wykorzystanie [Water resources and their use]. Nauka 1, 77-98. [in Polish]

Gómez P., Casado C., Sáenz Y., Ruiz-Ripa L., Estepa V., Zarazaga M., Torres C., Small K. 2017. Diversity of species and antimicrobial resistance determinants of staphylococci in superficial waters in Spain. FEMS Microbiol. Ecol. 93(1), 208. DOI:10.1093/femsec/fiw208.

Klapes N.A., Vesley D. 1986. Microbiology rapid assay for in situ identification of coagulase-positive staphylococci recovered by membrane filtration from swimming pool water. Apel. Environ. Microbiol. 52(3), 589-590.

Michałkiewicz M., Mądrecka B. 2009. Problematyka bakteriologicznego skażenia wód [Problems of bacteriological contamination of water]. Technol. Wody 2, 14-19. [in Polish]

Niewolak S. 2000. Bacteriological monitoring of rivers water quality in the north area of Wigry National Park. Pol. J. Environ. Stud. 9(4), 291-299.

Nollet L.M.L., De Gelder L.S.P. 2013. Handbook of water analysis. 3rd ed. Boca-Raton, CRC Press, Taylor@Francis Group, 784.

OECD. 2015. Report OECD environmental performance reviews: Poland. Paris, OECD Publishing. DOI: http://dx.doi.org/10.1787/9789264227385-en. 
Państwowa Stacja Sanitarno-Epidemiologiczna w Krakowie. 2015. Komunikat nr 2: Bieżąca ocena jakości wody w akwenie Przylasek Rusiecki w Krakowie, http://www.pssekrakow.wsse.krakow.pl/ /index.php/dzialania/nadzor-sanitarny/111-woda/nadzor-nad-jakoscia-wody-w-otwartych-akwenachwodnych/528-komunikat-nr-2-biezaca-ocena-jakosci-wody-w-akwenie-przylasek-rusiecki-w-krakowiemiejsce-wykorzystywane-do-kapieli-zbiornik-nr-1, access: 05.05.2017. [in Polish]

Państwowy Powiatowy Inspektorat Sanitarny w Krakowie. 2016. Nadzór nad jakością wody w otwartych akwenach wodnych, http://www.pssekrakow.wsse.krakow.pl/index.php/dzialania/nadzorsanitarny/111-woda/nadzor-nad-jakoscia-wody-w-otwartych-akwenach-wodnych, access: 25.03.2017. [in Polish]

Państwowy Powiatowy Inspektorat Sanitarny w Tarnowie. 2016a. Ocena jakości wody w miejscu wykorzystywanym do kąpieli przy ul. Polnej w Radłowie, http://pssetarnow.wsse.krakow.pl/attachments/ larticle/277/204\%20ocena\%20jakosci\%20wody\%20Radlow.pdf, access: 05.05.2017. [in Polish]

Państwowy Powiatowy Inspektorat Sanitarny w Tarnowie. 2016b. Ocena jakości wody w miejscu wykorzystywanym do kąpieli w Podlesiu Dębowym, http://pssetarnow.wsse.krakow.pl/attachments/ /article/277/206\%20ocena\%20jakosci\%20wody\%20Podlesie\%20Debowe.pdf, access: 05.05.2017. [in Polish]

PN EN ISO 6222 : 2004. Jakość wody. Oznaczanie ilościowe mikroorganizmów zdolnych do wzrostu. Określanie ogólnej liczby kolonii metodą posiewu na agarze odżywczym. [in Polish]

PN-EN ISO 7899-2 : 2004. Jakość wody. Wykrywanie i oznaczanie ilościowe enterokoków kałowych. Cz. 2. Metoda filtracji membranowej. [in Polish]

PN-EN ISO 8199 : 2010. Jakość wody. Ogólne wytyczne oznaczania liczby bakterii metodą hodowli. [in Polish]

PN-EN ISO 19458 : 2007. Jakość wody. Pobieranie próbek do analiz mikrobiologicznych. [in Polish]

PN-EN ISO 9308-1 : 2014-12. Water quality. Enumeration of Escherichia coli and coliform bacteria. Part 1. Membrane filtration method for waters with low bacterial background flora.

Rozporządzenie Ministra Zdrowia z dnia 8 kwietnia 2011 r. w sprawie prowadzenia nadzoru nad jakością wody w kąpielisku i miejscu wykorzystywanym do kąpieli. DzU z 2011 r., nr 86, poz. 478. [in Polish]

Rozporządzenie Ministra Zdrowia z dnia 9 listopada 2015 r. w sprawie wymagań, jakim powinna odpowiadać woda na pływalniach. DzU z 2015 r., nr 208, poz. 1240. [in Polish]

Seyfried P.L., Tobin R.S., Brown N.E., Ness P.F. 1985. A prospective study of swimming-related Illness II. Morbidity and the microbiological quality of water. AJPH 75(9), 1071-1075.

Van Elsas J.D., Semenov A.V., Costa R., Trevors J.T. 2011. Survival of Escherichia coli in the environment: fundamental and public health aspects. The ISME J. 5, 173-183.

Abstract. Microbiological contamination of waters used for recreational purposes may constitute a serious danger to the health of users. Only a few reservoirs in Lesser Poland are subjects of constant control and meet the microbiological criteria. The work was aimed at evaluating the degree of microbiological contamination of selected bathing areas in Małopolska voivodeship in the municipal areas Tarnow and Krakow. Samples were taken from 10 sampling points, three times in the period from June to October 2016. Microbiological analyzes of water were performed using membrane filtration and serial dilutions methods. The total number of mesophilic and psychrophilic bacteria as well as number of Escherichia coli, fecal streptococci (enterococci) and staphylococci were determined. In all examined reservoirs the occurrence of microbiological indicators of bad hygienic condition of water was confirmed. Numerous occurred bacteria of the species $E$. coli, which was the main reason for the water being taken to those that did not meet the bathing area requirements. More contaminated were bathings in the municipality of Kraków than Tarnów, but these were not statistically significant differences. The amount of psychrophilic bacteria in the waters was higher than mesophilic ones, suggesting that the main source of microorganisms is the natural environment. Recreational areas under constant monitoring were characterized by slightly less contamination, but rarely met criteria for bathing due to the large number of indicator bacteria. The biggest water pollution was found at the peak of the tourist season in August. Considering the average values of measurements only bathing "Katamaran" meet the requirements. 
